\author{
石 関 忠 一*
}

\title{
On the microbial contamination of cosmetics
}

\author{
Chuichi ISHIZEKI
}

This monograph includes the problem of microbial contamination of cosmetics, as well as the practical methods used for the microbiological control of cosmetics.

The microbial contamination was discussed separately as primary (contamination of the product itself) and secondary contamination (contamination by the consumer)

Author has reservations on the application of bacteriological standards for cosmetics at this time, however author's temporary proposal for then is as follows;

Viable aerobic count: less than 100 bacteria $/ \mathrm{m} l$ or gram.

Pathogenic bacteria: not detected.

None of the preservatives commonly used in cosmetics to-day is universally active against all kinds of microorganisms. Therefore, preservatives should be used only for the prevention of secondary contamination.

Auther tried to examine antimicrobial spectrum of some preservatives now commonly used in cosmetics. The results are shown in the table.

The readily applicable methods as a quality control produce to determine the total aerobic counts and pathogenic bacteria were described. In conclusion, it seems to author that a more logical approach and goal at this time is the production of cosmetics under controlled conditions to assuer maximum sanitation.

\section{1. 緒言}

日常皮膚が多くの環境污染によって何んらかの悪影響 を受けていることは周知の事実である。したがって皮膚 の機能を正常に維持するために多くの保護的手段がとら れているが化粧品もその一つであると思われる。しかし これとて皮膚からの吸収の問題あるいは製阂自体が微生 物污染のために変敗し, そのためある種の微生物によっ ては製剤中に有害な代謝産物の産生をまねくおそれが生 じてくるし，また一方では微生物による感染の問題もお きてくる。

最近とくに内外を問わず医薬品の安全性についての究 明が盛んになってきたことは非常に好ましいことである

* 東京都世田谷区上用賀1-18-1

国立衛生試験所衛生微生物部

National Institute of Hygienic Sciences 18-1,

Kamiyoga 1-Chome, Setagaya-ku, Tokyo, Japan Department of Microbiology
が微生物污染の問題も少なからずこれらの中に包含され てよいものと考えている。化粧品についてのこのような 問題は従来あまり顧りみられず安全性からみれば決して みのがすことはできない。化粧品の成分のなかには重金 属をはじめとして多くの色素類が, その安全性の観点か ら問題となっているが微生物污染に関してはあまり論究 の域に達していないのが現状と思われる。最近欧米では 化粧品と微生物污染の関係とくに病原菌に関心がもたれ てきていることは事実である122)314)5)。現在ではその剂 型も $\mathrm{o} / \mathrm{w}$ 型のものが多いようで従来のw/o 型のものに比 ベて水分含量が多い。またノニオン系界面活性剤の製剤 への応用も微生物污染が増加した一因とも考えられる。 以前はカチオン系あるいはアニオン系活性剤が多用され ていたようであるが，それ自身に抗菌活性があるためか 污染は比較的少なかったようである。一方微生物の増殖 がこのような製剤のいかなる相で起るかをみてみると， その多くは油相と水相との界面が最も多いとされている ことは微生物が水分に依存していることから理解され 
る。

消費者側からみれば化粧品が化学的に多くの有害物質 を包含していることも危険ではあるが微生物污染の問題 も重要である。この場合製品の変敗損失は第 2 問題でま ゔ生体のらける危険の方がはるかに重大である。

このように化粧品が微生物学的には多くの問題をかか えておりながら従来あまり議題の焦点とならなかったこ と自体ふしぎといわざるをえない。そこで本題のらち主 として試験法についての解説をとの依頼を受けたがそし 資料ではあるが日常著者の行なっている方法ならびに 考察をも含めて筆を執った次第である。なお読者の御意 考に沿いか叔る面も多々あることを扔許し願いたい。

\section{2. 污染源とその微生物}

污染は化粧品にかぎらず医薬品を含めて人工的に処理 加工されるほとんどの製品にあてはまる問題で大きく分 けて化学物質による污染と微生物による污染とに分けて 考えることができるが, 本議題では後者の微生物污染に 焦点を求めてみたい。

本来この問題を解くためには微生物污染が生体に与え る悪影響をいかに理解するか, あるいはその污染源をど のように究明するかにあると思われる。したがって製品 の損失は第 2 問題として処理されなければならない。

污染源と考えられるものに原料 (水を含む), 製造従事 者による污染, 付帯設備（製造環境や製造機器類とくに 釜, パイプライン, バルブ, 容器または保管場所, 充填 機）等がある。一言でいえばこれらがすべて無菌的な材 料扔よび操作のもとで衛生的処理工程をへて製造された ものであれば微生物学的にみて安全な製品が生産され消 費者に対する不安感を解消することもできると同時に製 品の損失をも防ぐことができる。

過去に扮いて主たる原因とされていたものに水がある と思う。従来イオン交換法による脱イオン水は一般にき れいな水と思われているが微生物学的にはかなり不純な 水と思わなければならない。かつて Baker (1959)6) は化 粧品の微生物污染がイオン交換水にあったことを報告し ている。これはイオン交換樹脂層に沈着した色々な有機 物が栄盖源となって微生物の生息を可能にしたことによ ると思われる。したがって製品に用いる水は蒸留水であ ろらとイオン交換水であらうとすべて滅菌処理過程をへ たものでなければ污染源としての可能性が十分に存在す ることになる。

製造工程以前の未精製物質については Schiller $\left.(1968)^{7}\right)$ らの報告によってもわかるように物質によって は化学的に精製されたものでも微生物の混在しているも
のもあるとのことにとくに注目しなければならない。そ れはこれらを処理した室の環境（空気・温度・湿度・ゴ ミ）容器, 包装あるいは処理にたずさわった人による污 染等が問題となるからである。また物理的, 化学的に処 理できえない物質もあるが，これらが製品化された場合 には相当な污染が生ずることはいうまでもない。また De Navarre (1969) ${ }^{8}$ ) は各種の天然活性物質の微生物污 染についての報告のなかで化粧品関係ではタルク中に 3,150ケ/g の生菌数をみとめたとしている。しからばこ のような各成分中の微生物はいかにしたら取り除くこと ができるかという問題が出てくるが，これは非常にむず かしいことである。なぜなら微生物を処理できる滅菌条 件下では成分によってその性質をかえてしまうことにも つながるからである。最近 Alquire (1970)9) は化粧品各 成分の微生物をコントロールする手段として $100 \%$ エチ レンオキサイド ( $\mathrm{E} \cdot \mathrm{O}$ と略す) による滅菌法を試み一般 細菌では $2 \times 10^{6}$ 個が 100 個以下に, また真菌では $3 \times 10^{2}$ 個のものが10個以下にできると報告している。しかしそ の利用については一長一短があり $\mathrm{E} \cdot \mathrm{O}$ に対して充分な理 解が必要となる。すなわちE・O法を確実に行なうために は温度・湿度・E・O濃度および加圧条件などが問題とな りまた使用条件によってはすべての微生物が滅菌できる とは限らず各成分の分解変質をもまねくおそれがある。 しかし適当な条件での利用によっては容器の滅菌も含め てかなり利用価值があるのではないかと思われる。

設備の点ではパイプ、ジョイントから充媜にいたる製 品残留物の付着や痕跡程度のものでも微生物蔓延の源と なる。すなわち目につかない污染源がいたる所にあるこ とになる。これらの処理について Davis $(1960)^{100}$ はれれ らプラントの消毒には次亜塩素酸塩の 150 200 ppm で 消毒が完全となるとしているが，一方この塩素の腐蝕性 やプラント内の残留が問題となってくるとしている。ま た製品の性質上いろいろな消毒剤の利用も好ましくな い。したがってその清浄法としては熱湯法が一番無難で あろう。

製品中で微生物の発育が一番よくみとめられる所とし ては容器内キャップ裏側より製品の表面および容器辺縁 等をあげることができる。これは多分に微生物の発育が 水分や空気と密接な関係にあることを示していると思わ れる。Noble (1966) $)^{4)}$ はステロイド入りクリームでの緑 膿菌污染の問題で $0.1 \%$ Chlorocresol の防腐剂が入 っているにもかかわらず緑膿菌污染がみとめられたこと について, 菌がクリームの油相と水相との界面に多くみ とめられた点よりして防腐剤が油相中に移行したため菌 が水相中およびその界面で発育したとの解釈をとってい 
る。Ayliffe (1965)5) らは緑膿菌が床, 下水あるいは投 薬ビンのキャップからも分離されたとし，また Tenenbaum $\left.(1971)^{3}\right)$ は化粧品中の緑膿菌污染の意義について興 味ある報告をしている。その中で本菌は污染菌中最もや っかいな菌であることを指摘しているが，これは今日， ニオン系界面活性剤が化粧品分野で主に使用されてきた ことと緑膿菌の污染頻度が高くなって来ていることに関 係がありそらである。たしかにこの菌は多くの抗菌剤に 対してかなり抵抗力を示す一方人に対する病原性むかな り報告されている。とくに緑膿菌がみとめられる条件と してノニオン系界面活性剤を含む製剂 $\mathrm{pH} 7.0$ ～8.5 の O/W 型乳剤であるとされているが，もちろんこのよう な製剤では他の污染菌も多々みとめられていることに注 意されたい。

次に今までのべたものを一次污染と考えるならば，製 品が消費者の手に渡って開封後に起るものを二次污染と することができる。たとえば広口ビンのごときは開封後 の空気由来の微生物が混入し, また柔軟性の容器では押 圧して内容液を出した後の容器の複元性による空気の吸 引あるいは使用時の手による污染等が日常起ることとし て予想できる。またここまで污染問題を拡大解釈する と，これを予防するために防腐㓮の使用が試みられるが 人に対する安全性からみれば多量の防腐剂添加は好まし からざる問題を提起するであろら。要は污染の根本原因 の探究によって製品自体よりの消費者側への污染を防ぐ ことが第1であって消費者側の手に渡ってからの二次污 染浪用者の衛生的観念の普及によってある程度防ぐこ とができるのではないかと思われる。しかし最少限の防 腐剤使用は必要であろう。本来防腐剤の使用は消費者よ りの二次污染を防ぐ目的で使用す心゙きであり防腐剤によ って製品中の菌を減らすことを考えるのは邪道である。 また防腐剤が污染可能なす心゙ての微生物に一様に効果を もつかどうかは疑問で今日化精品品質基準 $(1967)^{11)}$ で使 用が許可されている化粧品関係の防腐剂では単体で広い 抗菌スペクトルをもつものは殆んどない状態で，したが って今後は毒性の低、安全なかつ抗菌活性の広、防腐剤 の開発が望まれるところである。ここでBaker (1959)6)， Wedderburn (1964)12), Noble (1966)4) おょよ゙ Tenenbaum (1971) $)^{3)}$ 等の報告から化粧品中の污染菌を集め

Table-1 に示してみた。

このように多くの微生物が污染菌として検出されてい るが，これらのなかには多くの危険な微生物む発見され ていることに注目されたい。

なお Foter (1950)13) らはクリームや軟亭などの適用 場所に常在する微生物として Table-2 のような菌分布
Table-1 Some of the Microorganisms Isolated from Pharmaceutical and Cosmetic Emulsions.

\begin{tabular}{l|l}
\hline \multicolumn{1}{c|}{ Bacteria } & \multicolumn{1}{c}{ Fungi } \\
\hline Achromobacter sp. & Absidia \\
Aerobacter aerogenes & Alternaria* \\
Alcaligenes faecalis* & Aspergillus* \\
Bacillus pyocyanes & Citromyces \\
Bacilllus subtilis* & Cladosporium* \\
Escherichia coli & Dematium \\
Micrococcus sp. & Fusarium \\
Proteus vulgaris* & Geotrichum \\
Pseudomonas aeruginosa* & Helminthosporium \\
Pseudomonas fluorescens* & Hormodendrum \\
Sarcina sp. & Mucor* \\
Serratia marcescens & Paecilomyces \\
Staphylococcus aureus* & Penicillium* \\
Staphylococcus albus & Phoma \\
Streptococcus sp. $*$ & Pullularia \\
& Rhizopus* \\
& Stemphylium \\
& Thamnidium \\
& Trichothecium \\
& Verticillium \\
\hline
\end{tabular}

* Several different species of these genera have reported.

を報告しているので参考とするのもよいと思われる。

また Knüsel (1969) $)^{2)}$ らは各種化粧品中の生菌数につ いて防腐剤添加の場合は菌数が比較的少ないが防腐剤無 添加の製品では菌数の増加にあわせて緑膿菌も検出され たと報告している。Table-3.

\section{3. 製品中の污染菌測定法について}

試験には必ず対照実験をともならことは微生物の分野 においても同じであるが微生物ではこれに加えて無菌性 が必須の条件となってくる。また検体については試験目 的である製品中の微生物を保護すべく特定な化学的ある いは物理的処理（加熱）をさけ製品そのままの状態での 污染の程度を検すべきである。

微生物検査の処理段階において最も注意しなければな らないことは実験に用いるすべてのものが無菌的に処理 
Table-2 Microorganisms which MayBe Present at Site of Applitcation of Ointments, Creams, Jellies, etc.

\begin{tabular}{|c|c|c|c|c|}
\hline & Pus & Wounds & Skin & Eyes \\
\hline Staphylococci (sp) ........ & \multirow[t]{2}{*}{$\mathrm{X}$} & $\mathrm{X}$ & $\mathrm{X}$ & $\mathrm{X}$ \\
\hline Pneumococci..... & & $\mathrm{X}$ & $\mathrm{X}$ & $\mathrm{X}$ \\
\hline Streptococci (sp) ... & \multirow{5}{*}{$\begin{array}{l}\mathrm{X} \\
\mathrm{X} \\
\mathrm{X} \\
\mathrm{X}\end{array}$} & $\mathrm{X}$ & $\mathrm{X}$ & $\mathrm{X}$ \\
\hline B. subtilis ............... & & $\mathrm{X}$ & $\mathrm{X}$ & $\mathrm{X}$ \\
\hline B. anthracis....... & & & $\mathrm{X}$ & $\mathrm{X}$ \\
\hline Clostridia (sp) .......... & & $\mathrm{X}$ & & \\
\hline Corynebacteria (sp) & & $\mathrm{X}$ & $\mathrm{X}$ & $\mathrm{X}$ \\
\hline Mycobacteria (sp) ......... & \multirow[t]{4}{*}{$\mathrm{X}$} & $\mathrm{X}$ & $\mathrm{X}$ & \\
\hline Erysipelothrix................ & & & $\mathrm{X}$ & \\
\hline Actinomyces (sp) $\ldots$. & & & $\mathrm{X}$ & $\mathrm{X}$ \\
\hline Neisseria (sp) .................... & & & $\mathrm{X}$ & $\mathrm{X}$ \\
\hline Pseudomonas aeruginosa ................... & \multirow{5}{*}{$\begin{array}{l}\mathrm{X} \\
\mathrm{X} \\
\mathrm{X}\end{array}$} & $\mathrm{X}$ & $\mathrm{X}$ & $\mathrm{X}$ \\
\hline Escherichia coli ............................. & & $\mathrm{X}$ & $\mathrm{X}$ & \\
\hline Proteus vulgaris ............................. & & $\mathrm{X}$ & $\mathrm{X}$ & \\
\hline Borrelia vincentii ................ & & $\mathrm{X}$ & $\mathrm{X}$ & \\
\hline Non-bacterial forms (fungi, etc.) ......... & & & $\mathrm{X}$ & \\
\hline
\end{tabular}

Foter and Nisonger (1950) より

Table-3 Microbial content of topical preparations (ointments, creams, lotions, pastes)

\begin{tabular}{|c|c|c|c|c|c|c|}
\hline \multirow{3}{*}{$\begin{array}{c}\text { Number of } \\
\text { batch }\end{array}$} & \multicolumn{4}{|c|}{ Total count (per g) } & \multirow[t]{3}{*}{ Pseudomonas sp. } & \multirow[t]{3}{*}{ Enterobacteriaceae } \\
\hline & \multicolumn{2}{|c|}{ Bacteria } & \multicolumn{2}{|c|}{ Fungi } & & \\
\hline & $<100$ & $>10,000$ & $<10$ & $10-100$ & & \\
\hline 48 & 47 & $1^{*}$ & 48 & - & $1^{*}$ & - \\
\hline
\end{tabular}

* Liquid emulsion without preservative; a suitable preservative has since been added.

Knüsel, Hess and Lim (1969) より

されているものでなければならない。たとえばサンプル 容器, サンプリング器具 (スパーテル, ピペット等), 菌 数測定のための器具全般 (ピペット, 試験管, シャーレ等), 希釈液および培地等検体処理から菌数測定にいたる操作 も含めた一連のものがすべて無菌的でなければならな い。また培地についてはいろいろな処方により各自で製 造される場合もあるが今日では乾燥粉末培地として市販 されているものもあり，これを一定の濃度で水に溶かす ことにより滅菌後使用可能となる。しかしながら培地は 製造後必ず雑菌試験（30 $37^{\circ} \mathrm{C} に て 3$ 日間）を行ない滅 菌状態を試験した後でなければ使用可能とはならない。 それは滅菌が不完全なために培地中に混入した微生物が 発育したのか，あるいは検体由来の微生物かを判別でき ないからである。さらに厳密には検体処理前に培地の性 能試験をしなければならない。これはでき上った培地に
適当な微生物を接種してその培地が微生物の発育に対し てどのような態度を示すかを調らべるものであるが，ま ず特定培地を除いてはあまり心配ないようである。

一方コロニー（集落）として生ずる菌は検体中あるい は培地中を問わず菌が個々にばらばらの状態で存在しな いものもあり細胞分裂によって数個の菌が連鎖をつくっ て塊となっている場合もある。これは培地中では細胞集 団となって 1 個のコロニーをつくる。したがって 1 コ口 ニー 1 個の生菌という概念が常にあてはまるものでない ことに注意されたい。また測定される菌数も培地の組成 あるいは測定法等により異なった条件下で培養すると発 生する菌の数および種類も異なった結果となってあらわ れるゆえ常に一定条件下でのコロニーの発生能力をもつ 菌としての值を出すよう心がける心゙きである。しかしこ の值の信頼性がどらかとなると非常にむずかしい問題と 
なるがこれについては Stearman (1955)14)の報告を参考 にされるとよいと思われる。すなわち細胞の集塊によっ ては測定値も低い值として出ることや希釈誤差として のピペットや液量の問題がある。したがって終末計算と して同一処理検体について寒天平板培地および液体培地 ともそれぞれ少なくとも2 4 枚 (本) の成績をもって評 価すべきである。一般生菌数測定に関するものとしては Norris (1969)15) らや植村 $(1960)^{16)}$ らの著書を参考にす れば理解できるものと思われる。な打食品の場合は生菌 数の外にその污染の指標として大腸菌群をあげている が，著者は化粧品の場合外用面の使用を考慮に入れてブ ドウ球菌および緑膿菌を污染指標の対象としてはと考え ている。

ここでは種々の方法について文献をもととして著者の 行なっている方法も加味して順にあげてみたい。

\section{$3 \cdot 1$ 一般細菌の生菌数}

製品污染の程度を評価するためには以下の方法のうち 少なくとも 2 つ方法による測定結果によって行なわれ るべきである。

\section{$3 \cdot 1 \cdot 1$ 寒天平板混採法}

1) 検体の採取

製品にあっては未開封の容器から無菌的操作により検 体を採取して試験に供するがその他の検体例えば製造工 程中のものあるいは製品の材料にあっては滅菌したサン プル容器に無菌的に採取し検体とする。

試験量は, 通常固体の場合は $1 \mathrm{~g}$, 液体は $1 \mathrm{~m} l$ を 1 回 量としさらに採取場所をかえて 2 3 回同じ操作で採取 する。

\section{口) 検体の希釈}

滅菌希勫液で 10，100，1000倍（污染の程度によりこと なる）と希勫しらすめた検体はできるだけすみやかに培 養操作にうつる。

通常 1 検体 (1 希橎液)につきシャーレ 2 枚を用いる。 平板培地に発生するコロニ一数は Postgate (1969) $\left.{ }^{17}\right)$ に よれば200 300個の範囲内になるように希釈して菌数を 測定するのが理想的とされている。一方衛生検査指針 (食品または飲料水編) $\left.{ }^{18}\right)^{2}$ では培養後 $30 \sim 300$ 個のコロニ 一が生ずる程度に希釈するとしている。しかし実際には 検体が未知の場合が多い。たとえば原液で数個というよ らなときには検体の濁りの問題も考慮にいれなければな らず一概にこれを論ずることは困難である。要は検体由 来の菌であるか, あるいは操作によって混入した菌であ るかを対照実験によってみきわめることの方が重要であ る。

\section{八）培養操作}

検体 $1 \mathrm{~g}(1 \mathrm{~m} l)$ を希釈液で溶解および懸濁をかねて浸 出し適当な濃度に希釈する。この各希釈液 $1 \mathrm{~m} l$ づつを 2 枚のシャーレに分注し，あらかじめ溶かして約 48〜 $53^{\circ} \mathrm{C}$ に保った菌数測定用寒天培地 $9 \mathrm{~m} l$ ら゙っを加えて培 地がシャーレ内で固まらないらちに前後左右に回転させ て検体と培地とがよくまざるようにして固まったシャー レを逆さにしてフラン器内で $24 \sim 48$ 時間培養する。平板 （混釈された）はたくさん積みかさねたり他のもので包 む（例ビニール）よらなことはしない。

二) 菌数計算

培養後発生コロニーの数が200 300個 (30 300個) く らいの希釈段階でのコロニ一数を数えこれに希釈培数を 乗じて検体 $1 \mathrm{~g}(1 \mathrm{~m} l)$ 中の菌数とする。この際24時間培 養と48時間培養とでは若干菌数に差を生ずるが結果は通 常48時間値で求める。ただし拡散性の強い菌の場合には 24時間值の平均コロニ一数で表わすこともある。

$3 \cdot 1 \cdot 2$ 寒天平板塗抹法

本法は現在日本抗生物質医薬品基準 $\left.(1969)^{19}\right)$ で生菌数 測定に用いられているものに著者が若干補正したもので ある。検体 $1 \mathrm{~g}(1 \mathrm{~m} l)$ 中の生菌数を求めるのであるが眼 軟高ではその生菌数が50個以下と規定されている。

菌数試験用寒天培地 (普通寒天培地- Trypticase soy agar も使用可能)をとかし $48 \sim 53^{\circ} \mathrm{C}$ に保温したもの 20 $\mathrm{m} l$ づつをシャーレ（直径 $90 \sim 100 \mathrm{~mm}$ ) に分注して均一 にかためて平板とする。検体は容器ごと正確にはかり 30 $\sim 35^{\circ} \mathrm{C}$ に約 1 時間放置したのちその $0.1 \sim 0.3 \mathrm{~g}$ を試料 として, あらかじめ $30 \sim 35^{\circ} \mathrm{C}$ に保温して抢いた平板の らえに検体をのせた後に検体を再び容器ごと正確にはか り試験に用いた検体量を換算する（液体の場合は $0.1 \sim$ $0.3 \mathrm{~m} l)$ 。

次に平板にうつされた検体を滅菌ガラス棒（コンラー ジ棒) で平板上に均等にひろげ $30 \sim 37^{\circ} \mathrm{C}$ で 48 時間培養 する。培養後平板上のコロニ一数をかぞえて検体 $1 \mathrm{~g}$ (1 $\mathrm{m} l$ ) 当りの生菌数を算出する。

このような操作はすべて無菌的に行ならことはもちろ んであるが検体中の污染菌が拡散性の強い菌の場合ある いは污染の程度によっては希釈液の塗抹法によることも ある。な抢塗抹に用いる検体量は $0.3 \mathrm{~g}(0.3 \mathrm{~m} l)$ までで これ以上の量では寒天培地にしみ込まない場合があるの で注意を用する。（日本抗生物質医薬品基準では $0.1 \sim$ $0.5 \mathrm{~g}(\mathrm{~m} l)$ とある $)$

$3 \cdot 1 \cdot 3$ 液体培地階段希橎法

検体 $1 \mathrm{~g}(1 \mathrm{~m} l)$ を希䣋液（接種される液体培地を用い る場合もある) で無菌的に 10,100 ，あるいは 1,000倍と 
希䣋して, その検体浮遊液を一定量づつ液体培地に接種 する。接種法は液体培地 $9 \mathrm{~m} l$ に検体希釈液 $1 \mathrm{~m} l$ を接種 して $30 \sim 37^{\circ} \mathrm{C}, 24 \sim 48$ 時間培養後菌の発育の有無を濁 りで判定する方法である。USP. XVIII (1970) ${ }^{21) 。 こ の ~}$ 方法は菌の発育がコロニーとしてみられず蜀りによるた め検体による濁りを考慮に入れるべきである。判定が困 難な場合には一定時間培養後（24 時間）その 1 白金耳を 塗抹量として寒天平板上にうつすか, $0.1 \sim 1.0 \mathrm{~m} l$ まで の濁りをうつさない程度の適当量を同じ液体培地に再接 種して $30 \sim 37^{\circ} \mathrm{C}, 24 \sim 48$ 時間培養後判定する。なお発育 疑わしき溷濁培地から直接叙抹染色標本 (Gram 染色) を作り顕微鏡観察するのも一法である。

3.1.4 Woodward (1971) ${ }^{20)}$ らの液体培地階段希釈法 本法では一般生菌数（細菌・真菌）のほか特定細菌 （病原菌む含む）の検出にも利用されている比較的よい 方法であると思われる。Fig.1, Table-4

検体の希釈㧤よび培養操作：一般細菌の場合

図解されているように検体 $1 \mathrm{~g}(1 \mathrm{~m} l)$ を $\mathrm{BHI}$ 液体培 地 $9 \mathrm{~m} l$ 入りの試験管 No. 1 に入れてよく混和し 10 倍液

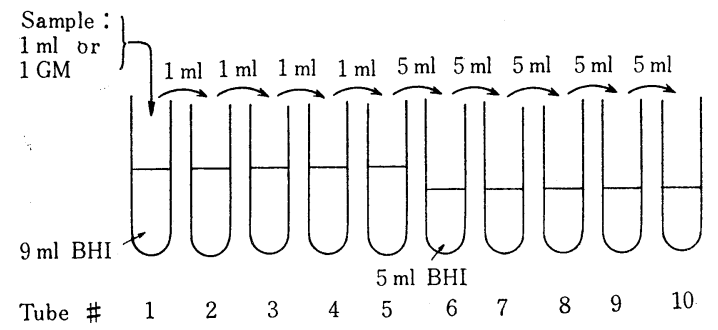

Fig-1 Scheme for mixing and diluting sample deing tesled. See also paragraph A. Phasei(A) for further discussion
を作る。次にこれより順次その $1 \mathrm{ml}$ を No. 2 にうつ してこの操作を試験管 No. 5 まで行ない, No. 5 からは 各 $5 \mathrm{~m} l$ をNo. 6 以後の試験管に希釈をか子衫て順次うつ しかえて培養にうつる。培養は $37^{\circ} \mathrm{C}, 25 \sim 48$ 時間行な いその発育した試験管番号より Table-4 に示されてい るように菌数を算出する。たとえば試験管 No. 6 に発育 して No. 7 に発育しない時は表の読みから少なくとも 100,000 個/ $1 \mathrm{gm}(1 \mathrm{ml})$ とし200,000個/1 gm以下である と表わす方法である。

$$
3 \cdot 1 \cdot 5 \text { メンブランフイルター法 }
$$

本来この方法は無菌沪過法と呼ばれ変性しやすい蛋白, 酵素および不安定な物質等の水溶液から微生物を取り 除くために使用されてきた。これは現在 USP.XVIII'1) およびNF. XII ${ }^{22}$ 等においてその使用が規定され医薬品 の検査に応用されているが，わが国ではまだ公定書に入 れるまでにはいたっていない。污染の程度が比較的低い 大量の液体中より，ごくわずかな微生物を検出する場合 には特に好都合である。なおこの装置とその使用にさい

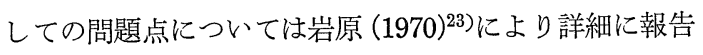
されているので参照されたい。

本法の原理は一定サイズの沪孔（例えば $0.2 \mu, 0.45 \mu$ その他）をもつフィルターを装着して適当な沪過速度で 減圧汇過を行ならことにある。この場合検体中に多くの 微生物が混入しているようなときには菌数に応じて検体 を希釈してから沪過するか, あるには少量を沪過した後 フイルターを寒天平板培地上におくか液体培地中に無菌 的に入れて培養する。平板培地の場合は沪過された微生 物がコロニーとして生ずるが液体培地の場合には濁りに よる発育しかわからない。したがって污染菌の数または 種類を早急に知りたい時には平板培地上での培養が好ま

Table-4

Growth in (tubes)

The Ist tube but not the 2nd

The 2nd tubes but not the 3rd

The 3rd tubes but not the 4 th

The 4th tubes but not the 5th

The 5 th tube but not the 6 th

The 6 th tube but not the 7 th

The 7 th tube but not the 8 th

The 8 th tube but not the 9 th

The 9 th tube but not the 10 th

The 10th tube
Equals: At least organisms/ML or GM

$\begin{array}{rr}1 & 10 \\ 10 & 100 \\ 100 & 1,000 \\ 1,000 & 10,000 \\ 10,000 & 100,000 \\ 100,000 & 200,000 \\ 200,000 & 400,000 \\ 400,000 & 800,000 \\ 800,000 & 1.6 \mathrm{M} \\ 1.6 \mathrm{M} & \end{array}$

Woodward and Mc Namara (1971) より 
しい。ここで Knüsel (1969)2) らが医薬品中の微生物污 染をこの方法を用いて実験しているので引用してみたい と思う。Fig.-2 扮よび Table-5 に示されているように 同一Lot の検体を少なくとも 3 つの容器から無菌的に 採取したものを混合して，それを目的別に沪過して培養

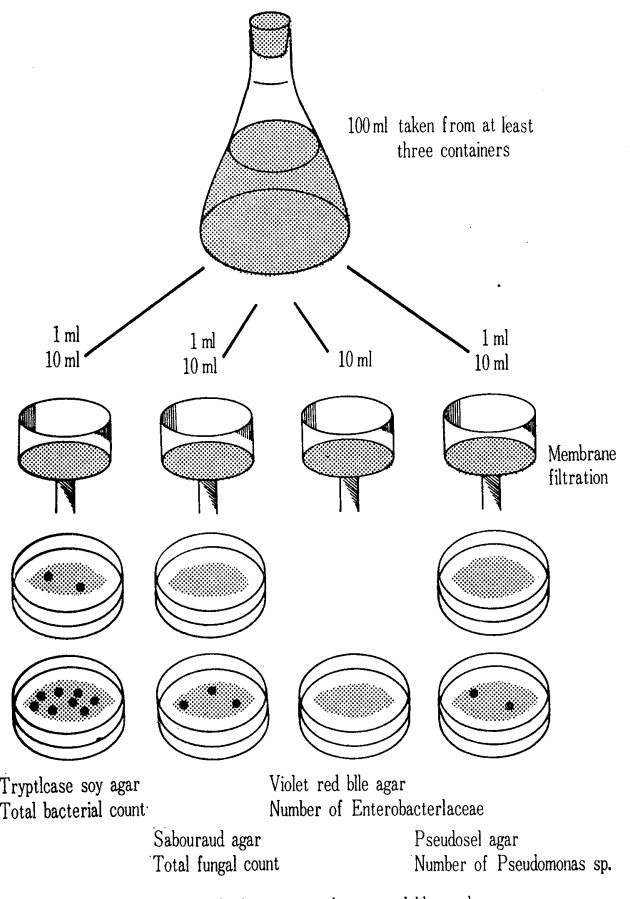

Microbiological control of aqueous and water-soluble products.

Fig-2 Knüsel, Hess and Lim (1969) より
にうつす方法である。すなわち検体を沪過したフイルタ 一を個々の菌別に撰択培養することにより同一検体から 生菌数（細菌・真菌）および特定菌にいたるまでを同時 に行なら方法である。

$3 \cdot 6 \cdot 6$ 特定細菌の鑑別培養について

一般細菌の希釈系列で発育のみとめられたものからそ れぞれの撰択培地を用いて特定細菌の検出を試みる。す なわちまづ希橎系列で一番高い発育試験管から塗抹標本 を作ってグラム染色を行ないその染色性から次のように 培地を選んで培養する。

グラム陽性の場合：V一J 培地一ブドウ球菌用

グラム陰性の場合：MEB 培地一大腸菌用

グラム陰性の場合: $\mathrm{BiSO}_{3}$ 培地一サルモネラ用

グラム陰性の場合：UTB 培地一プロテウス用

グラム陰性の場合：PsA 培地一緑膿菌用

このような培養により特定菌株の予備的同定試験を行 ならことができるが，できればこの培地使用に際しての 対照として既知の菌株を同種培地に培養してその判別に 利用した方がよいと思われる。

\section{$3 \cdot 6 \cdot 7$ 嫌気性細菌}

本来ならば一般細菌と同様に取り扱らべきであるが本 菌の性質上特殊な装置と培地とを必要とする。また製品 の使用場所よりすれば特殊の場合を除いては試験価值は 少ない上うである。しかしその検出にあたっては日本薬 局方第 8 改正の無菌試験細菌用培地に検体を接種するこ とにより定性的には検出可能である。

\section{$3 \cdot 2$ 真菌の検査法}

真菌は元来ごく一部の菌すなわち酵母類を除いては多 くは形態学的分類によって分けられ一般細菌のごとく生

Table-5 Summary of pathogenic bacteria mixed together, media employed, and results obtained in order to verify the presence of each on specified differential media.

\begin{tabular}{|c|c|c|c|}
\hline \multirow{3}{*}{$\begin{array}{l}\text { Identification of } \\
\text { Staph. aureus }\end{array}$} & \multirow{3}{*}{$\begin{array}{l}\text { Media employed } \\
\text { V-J }\end{array}$} & \multicolumn{2}{|c|}{ Results } \\
\hline & & Biochemical & Gram stain \\
\hline & & $\begin{array}{l}\text { Black colonies surrounded by } \\
\text { clear zones, indicating mannitol } \\
\text { formulations }\end{array}$ & Gram + cocci only \\
\hline & Staph 110 & Deep yellow colonies & Gram + cocci only \\
\hline Ps. aeruginosa & Pseudosel & Green pigment produced & Gram-small rods only \\
\hline Proteus vulgaris & Urease broth & Positive for urease production & Gram-rods only \\
\hline Sal. oranienburg & SS & Not clearly defined & Gram-rods only \\
\hline & $\mathrm{BiSO}_{3}$ & Metallic black coionies & \\
\hline E. coli & EMB & No metallic sheen & Gram-rods only \\
\hline
\end{tabular}

Woodward, Mc Namara (1971) りよ 
化学的あるいは血清学的分類のできるのは一部の酵母類 とされている。したがってその分類にあたってはより専 門的な知識と経験とを必要としている。真菌の多くは好 気的でその増殖には多量の酸素を必要とし培養温度は細 菌に比して低く $20 \sim 25^{\circ} \mathrm{C}$ が至適とされている。一方栄 養素の面では細菌が窒素源を主にするのに反して真菌は 炭素源を主とするものが多く $\mathrm{pH}$ \& 5 6 の酸性側を好 むものがほとんどである。これに加えて重要なことは湿 度である。すなわち湿度10\%から生えはじまる真菌があ るが多くは70\%以上を必要とするとされている。

\section{$3 \cdot 2 \cdot 1$ 寒天平板塗抹法}

もっとも普通に行なわれている方法であるが製品の污 染の程度あるいは高濃度の防腐剂添加製品では希釈液に ついて行なら場合もある。

製品そのままを原液とする場合または $1 \mathrm{~g}(1 \mathrm{~m} l)$ 希釈 液 $(\mathrm{P} \cdot \mathrm{D}$ 液体培地を用いる場合もある) で適当にうすめ たものを検体とする。検体を $0.1 \sim 0.3 \mathrm{~g}(0.1 \sim 0.3 \mathrm{ml})$ 同定用真菌平板培地上に塗抹して $20 \sim 25^{\circ} \mathrm{C}, 1 \sim 2$ 週間培 養して発生するコロニーを観察する。

\section{$3 \cdot 2 \cdot 2$ 液体培地階段希釈法}

本法は従来も行なわれていたが，最近 Woodward $(1971)^{20)}$ らによって報告されている方法に著者の考えも 若干入れてまとめてみた。

$3 \cdot 1 \cdot 4$ の一般細菌の場合に準じて行なうが培地を細菌 用から真菌用に変える。製品 $1 \mathrm{~g}(1 \mathrm{~m} l)$ を P.G 液体培 地 (SD 液体培地でも可) $9 \mathrm{~m} l$ に入れてよく混和し10倍 あるいは 100 倍階段希釈とする。培養は $20 \sim 25^{\circ} \mathrm{C}, 1$ 2 週間行ない菌の発育の有無を検べる。ただここで一般 細菌のごとく Table-4 より菌数を算出するのが真菌の 場合にあてはまるかどらかは疑問である。しかし参考に はなるのでこれより寒天平板上にうつしかえて観察する のもよいと思われる。

\section{$3 \cdot 2 \cdot 3$ 純培養法}

AおよびBで発生した菌は純培養を行なったのちその 菌の形態学的あるいは生理的性質などをしらべることに よって菌種同定を行ない防腐剤の抗菌活性との関係の資 料となしうることは一般細菌の場合と同じである。

1) 培地の撰択

POA，PDA，ZPA，および SDA 等多くの同定用寒天 培地が用いられるが一般細菌の混入を防ぐ手段をとる場 合がある。通常上記培地にストレプトマイシン $(30 \sim 100$ $\mu \mathrm{g} / \mathrm{m} l)$ やニペシリン $(20 \sim 100 \mathrm{U} / \mathrm{m} l)$ などを加えた培 地での分離培養も試みられている。

2) 分離操作

発育したコロニーは白金鈎（白金線の先をカギ形に曲
げたもの）で胞子のできているものは胞子だけを，また 菌系体のものはごく一部を静かに周囲の異種コロニーに ふれないように鈎菌して斜面培地にうつして培養する。 このようにして純培養できた菌株は同定試験を行なわな ければならないがこの試験はかなり専門的知識を必要と する関係上専門家に依頼された方がよいのではないかと 思われる。

$3 \cdot 3$ 培 地

$3 \cdot 3 \cdot 1$ 水: 脱イオン水, 蒸留水 $121^{\circ} \mathrm{C} 20$ 分高圧蒸 気滅菌

$3 \cdot 3 \cdot 2$ 希釈液：緩衝生理食塩水

a 液: $0.2 \mathrm{M} \mathrm{KH}_{2} \mathrm{PO}_{4}$ (M. W. 136.24)

b 液: $0.2 \mathrm{M} \mathrm{Na}_{2} \mathrm{HPO}_{4}$ (M. W. 141.98)

$0.85 \% \mathrm{NaCl}$ 液 $1900 \mathrm{~m} l$ に a 液 $20 \mathrm{~m} l, \mathrm{~b}$ 液 $80 \mathrm{~m} l$ を 加える。 $\mathrm{pH} 7.2$ になるように $\mathrm{a}, \mathrm{b}$ 液を適宜増減して 調製する。 $121^{\circ} \mathrm{C} 20$ 分高圧蒸気滅菌。

$3 \cdot 3 \cdot 3$ 細菌用培地

1) 菌数試験用寒天培地

$\begin{array}{lr}\text { ペプトン } & 10 \mathrm{~g} \\ \text { 肉エキス } & 5 \mathrm{~g} \\ \text { 食 塩 } & 2.5 \mathrm{~g} \\ \text { 寒天 (粉末) } & 15 \mathrm{~g}\end{array}$

蒸 留 水 $1.000 \mathrm{ml} \mathrm{pH} 7.0$ (修正液・水酸化 ナトリウム液) $121^{\circ} \mathrm{C}$, 20 分, 高圧蒸気滅菌

ㅁ) Trypticase Soy Agar: BBL (1968) 25$)$

Trypticase peptone $15 \mathrm{~g}$

Phytone peptone $\quad 5 \mathrm{~g}$

食塩 $5 \mathrm{~g}$

寒天 (粉末) $15 \mathrm{~g}$

蒸留水 $\quad 1.000 \mathrm{ml} \mathrm{pH} 7.0,121^{\circ} \mathrm{C}$,

20 分高圧蒸気滅菌

八) Brain Heart Infusion Broth (BHI と略す)：一般 細菌用：BBL(1968)25)この培地は各自で調製される ものよりも市販さている製品の使用をすすめたい。

二）撰択培地：BBL (1968) ${ }^{25)}$

Vogel-Johnson Agar(V-J と略す) ブドウ球菌用 Eosin Methylene Blue Agar (EMB と略す) 大 腸菌用

Pseudosel Agar=Cetrimide Agar (PsAと略す) 緑膿菌用

Bismuth Sulfite Agar $\left(\mathrm{BiSO}_{3}\right.$ と略す) サルモ ネラ用

Urease Test Broth (UTBと略す) プロテウス用 
$3 \cdot 3 \cdot 4$ 真菌用培地

1) Potato Dextrose Agar (PDA と略す)

$\begin{array}{lrl}\text { ジャガイモ浸出液 } & 200 \mathrm{~g} \\ \text { ブドウ糖 } & 20 \mathrm{~g} \\ \text { 寒天 (粉末) } & 15 \mathrm{~g} & \\ \text { 蒸留 水 } & 1.000 \mathrm{ml} \quad \mathrm{pH} 5.6 \text { (無修正) }\end{array}$

$121^{\circ} \mathrm{C}, 15$ 分, 高圧蒸気滅菌

口) Czapek Dox Agar (CDA と略す)

$\begin{array}{lr}\mathrm{NaNO}_{3} & 3 \mathrm{~g} \\ \mathrm{KH}_{2} \mathrm{PO}_{4} & 1 \mathrm{~g} \\ \mathrm{KCl} & 0.5 \mathrm{~g} \\ \mathrm{MgSO}_{4} \cdot 7 \mathrm{H}_{2} \mathrm{O} & 0.5 \mathrm{~g} \\ \mathrm{FeSO}_{4} \cdot 7 \mathrm{H}_{2} \mathrm{O} & 0.01 \mathrm{~g}\end{array}$

ブドウ糖(またはショ糖) $30 \mathrm{~g}$

寒天 (粉末) $15 \mathrm{~g}$

蒸留水 $\quad 1.000 \mathrm{ml} \mathrm{pH}$ 約5.5(無修正)

$121^{\circ} \mathrm{C}, 15$ 分, 高圧蒸気滅菌。(なおこれにペプ

トンを $1 \%$ に加えて使用することもある)

八) Sabouraud Dextrose Agar (SDA と略す)

$\begin{array}{lr}\text { ブドウ糖 } & 40 \mathrm{~g} \\ \text { ペプトン } & 10 \mathrm{~g} \\ \text { 寒天 (粉末) } & 15 \mathrm{~g} \\ \text { 蒸 留 水 } & 1.00 \mathrm{~m} l \quad \mathrm{pH} \text { 約5.6(無修正) }\end{array}$

$121^{\circ} \mathrm{C}, 15$ 分, 高圧蒸気滅菌

二）無菌試験用真菌培地 (日局第 8 改正) ${ }^{24)}(\mathrm{PGA}$ と 略す)

$\begin{array}{lr}\text { 酵母エキス } & 2 \mathrm{~g} \\ \text { ブドウ糖 } & 20 \mathrm{~g} \\ \mathrm{MgSO}_{4} \cdot 7 \mathrm{H}_{2} \mathrm{O} & 0.5 \mathrm{~g} \\ \text { ペプトン } & 5 \mathrm{~g} \\ \mathrm{KH}_{2} \mathrm{PO}_{4} & 1 \mathrm{~g} \mathrm{pH} \text { 約5.6 (無修正) }\end{array}$

蒸留水 $(1.000 \mathrm{~m} l$

$121^{\circ} \mathrm{C}, 15$ 分, 高圧蒸気滅菌（場合によっては 寒天培地として寒天1.5\%に加える場合もある)

\section{4. 防腐剤加製品の防腐試験}

製品を微生物污染から防ぐためには使用に供するすべ ての材料および操作が無菌的に処理されればできること であるが，しかし数ある微生物すべてを対象とした場合 相当にむずかしい問題となる。微生物を滅菌処理できる 条件では製品中に含まれる各成分をそのままの状態で保 持できるか否かが疑問となる。また製品の性質上一度に 使用されてしまうようなものでなく長いものになると 2 〜 3月にもわたって使用されその間適当な所に放置さ れる場合があり，その間に使用者の手による二次污染も
関係してくる。したがって長期使用に耐えられるように するためには防腐剤の使用にたよらなければならなくな る。しかしこの防腐剤とてその単体ではかなりの抗菌 活性を示すものでも製品中の各成分との適合如何によっ ては本来の防腐作用が発揮されない場合やその作用の減 弱もみられるよらになる。したがって製剤中での防腐剤 と各成分との間の適合性を物理化学的あるいは薬学的に 究明しなければならないが防腐剤を主に考えた場合，そ の適合性の良否は微生物学的試験によって十分に解明さ れなければならないと思われる。ここで製剤中のどのよ うな所で微生物が発育するか, また防腐㨈の効果に影響 する因子についての究明が必要となるがそれには Wedderburn (1964) ${ }^{12}$ )の報告を参考にと思い Fig.-3 に示し た。

かつて Lawrence $(1950)^{26)},(1954)^{27)}$ は化粧品への 第 4 級アンモニウム塩の殺菌菌効果よりみた利用につい て，また各種防腐郕を用いた場合の中和剤に関する研究 もその適合性に関する一端でもある。とくに Quisno $(1946)^{28)}$ は第 4 級アンモニウム塩の殺菌効果を評価する 場合にはノニオン系ツイーン80やレシチン加培地を使用 するのがよいとしているが Klarmann (1948)29) らはそ の不活化剤として, Bacto-oxygall の利用について，ま た Brown (1964)30) らはツイーン80が第4 級アンモニウ ム塩やクロールヘキシジン醋酸塩の活性を不活化させる としている。一方青木 $(1957)^{31}$ らはパラオキシ安息香酸 エステル類の抗菌性はツイーン20で影響されると報告し ている。防腐荗は過去においては多くのものが使用され てきたが，それらのなかには安全性の問題から今日では 使用禁止のものも多々ある。最近, Gucklhorn (1970) ${ }^{32}$ はいろいろな殺菌剤がどのような作用をもつか，ある いは細菌や真菌に対して作用面から報告しているので Table-6 に示した。これによると従来から比較的優れて おりその使用頻度も高いフェノール系あるいはクロール 系等が意外によくないことがわかる。このようにみてみ るとカチオン系活性剤の抗菌性あるいは他の抗菌剤がい ろいろなものによってその作用が不活化される現象がわ かるが, 今日污染菌の中で, 最もやっかいでかつ危険と 思われる緑膿菌に対する研究にも注目すべきである。 Croshaw (1964) 33 ) らは緑膿菌を目標とした抗菌剤の研 究で肪脂族ハロゲン化ニトロ化合物が $12.5 \sim 50 \mu \mathrm{g} / \mathrm{m} l$ で活性を示しかつツイーン80やレシチンなどによる不活 性化もみとめられなかったとしている。また Schuster $(1971)^{34)}$ らはいろいろな界面活性剤とパラクロロメタ クレゾールとの適合性は一定の条件下で使用されるなら ば効果が得られるとしている。 


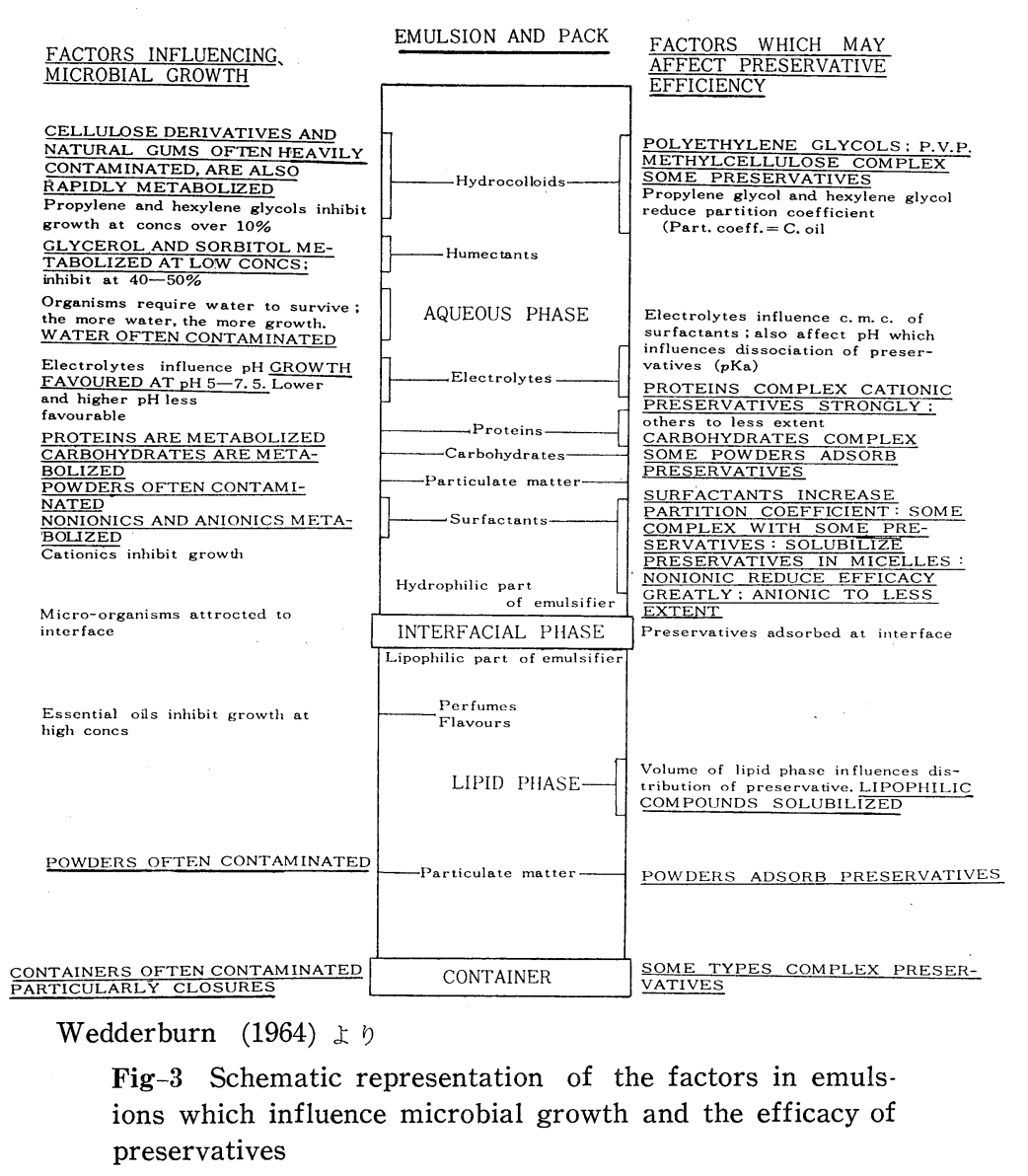

に記してみたい。なお防腐剤の効果 を試験するためにはその代表とし て使用される試験菌をきめなくて はならないが,この点については Wedderburn (1964)12) や USP XVIII'21)の記載にあるよらにTable7 に集録した菌株について著者も今 までの経験からよい選らびかただと 思っている。

\section{$4 \cdot 1$ 液体培地階段希䣋法}

主として Klarmann (1956) ${ }^{35)}$, Wedderburn (1962)12), Norris $(1969)^{15)}$ らおよび Woodward $(1971)^{20)}$ らの報告よりまとめたも のであるが著者の考えも若干考慮に 入れた。

[操 作]

二列の試験管系 (希釈段階によっ ては試験管に増減がある）を用意す る。

イ）一列目の試験管系：防腐剂単 体を種々の濃度に階段希釈してその 希釈濃度を含む培地を各々 $9 \mathrm{~m} l$ ゔ つ分注（希採液こして液体培地を使 用しても可)

口）二列目の試験管系：防腐。剤添 加製品を種々の濃度に階段希釈しその希釈濃度を含む培 地を各々 $9 \mathrm{~m} l$ づつ分注

これらイ), 口)の各濃度別の試験管に一定量の試験菌 を接種して $30 \sim 37^{\circ} \mathrm{C}$ （試験菌の種類によって至適温度
このように防腐剤と各成分との間の適合性に関する研 究はその多くが微生物学的試験によってその効果を評価 する方法をとっている。したがって製品中の防腐剤がい かなる効果をもっているかに関する試験法について簡単

Table-6 Properties of Disinfectants

\section{Detergency}

Bacteristasis

Fungistasis

Sporistasis

Soap and surfactant compatibility Prolonged activity on substrates Affinity for fabric

(a) in launder cycle

(b) in rinse cycle

Activity with soil

Mildness in handing

$\begin{array}{llllll}\text { SBT-24 } & \text { Phenolics } & \text { QACs } & \text { Organo-metals } & \text { Iodophors } & \text { Chlorine } \\ \text { excellent } & \text { fair } & \text { poor } & \text { poor } & \text { poor } & \text { poor } \\ \text { excellent } & \text { excellent } & \text { excellent } & \text { excellent } & \text { excellent } & \text { excellent } \\ \text { excellent } & \text { fair } & \text { poor } & \text { excellent } & \text { fair } & \text { fair } \\ \text { excellent } & \text { poor } & \text { fair } & \text { excellent } & \text { good } & \text { good } \\ \text { excellent } & \text { fair } & \text { poor } & \text { excellent } & \text { poor } & \text { fair } \\ \text { excellent } & \text { fair } & \text { fair } & \text { excellent } & \text { poor } & \text { poor } \\ & & & & & \\ \text { excellent } & \text { poor-fair } & \text { poor } & \text { excellent } & \text { poor } & \text { poor } \\ \text { excellent } & \text { poor-fair } & \text { excellent } & \text { excellent } & \text { poor } & \text { poor } \\ \text { good } & \text { fair } & \text { poor } & \text { fair } & \text { poor } & \text { poor } \\ \text { excellent } & \text { fair } & \text { fair } & \text { poor-fair } & \text { excellent } & \text { fair }\end{array}$

\footnotetext{
Gucklhorn (1970) より
} 
Table-7 Test organisms

\begin{tabular}{lc}
\hline \multicolumn{1}{c}{ Gram Positive } & \multicolumn{1}{c}{ Gram Negative } \\
Staphylococcus aureus* & Pseudomonas aeruginosa \\
Streptococcus mits & Escherichia coli* \\
Bacillus subtilis & Aerobacter aerogenes \\
\multicolumn{1}{c}{ FuNGI } & YeAsTs \\
Aspergillus niger* & \\
Penicillium chrysogenum & Candida albicans* \\
Alternaria solani &
\end{tabular}

\section{Wedderburn (1964)}

* USP XVIII (1970) にも含まれている菌種

を異にする)，24〜 48 時間培養後，接種菌の発育程度に より判別する。なおこの場合の対照はイ）の場合は防腐 剤の入らないものを，また口）の場合は防腐剤の入らな 、製品の同希釈液とする。

一般細菌は通常 $10^{4} \sim 10^{5}$ 個 $/ \mathrm{m} l$ を $1 \mathrm{~m} l$ 接種, 真菌の 場合は斜面寒天培養から 1 白金耳を $5 \mathrm{~m} l$ の䀣濁液にて 胞子懸濁液を調製し，その 1 白金耳量をそれぞれに接種 する。接種菌量は随時適当にかえて行なう。これは接種 菌量によっては得られる結果もことなるからである。

八）希釈液：リン酸緩衝食塩水または試験に用いる液 体培地を用いる。

二) 培地：普通ブイヨン, Trypticase Soy Broth, Brain Heart Infusion Broth，合成培地（それぞれの菌 株にかなった培地を選ぶ)，真菌の場合は主として日局 第 8 改正真菌用液体培地あるいは Sabouroud Broth が 用いられる。

ホ）その他：この試験で対照となる防腐剤単体の系で はそれに用いるが培地は通常その試験菌にかなったもの が用いられるが，それは普通培地の場合培地成分によっ て防腐剤の作用が影響をらけることがあるからである。 一方蛋白加製剂の場合はこれとは逆に培地に血清や卯等 を入れた培地での対照実験が必要となる。しかし微生物 の発育に敏感な $\mathrm{pH}$ は元来製品の $\mathrm{pH}$ に近づけたものが 使用されるが，す心゙ての試験菌にこれを適用することは できない。したがって個々の菌に対して至適に近づける ことが必要である。接種菌は一般細菌の場合ブイヨン培 養菌を遠沈操作により希釈液にて $3 \sim 4$ 回無菌的に洗ら い培地成分を除きかつ接種菌数を一定にする方法がとら れている。なおこの方法は防腐剂と他の処方成分間との 相関をみるのには便利である。

\section{$4 \cdot 2$ 寒天培地法}

この方法は寒天が基礎をなしている関係上防腐剤の活
性が若干低くあらわれる可能性があるとされている。 Foter(1950)13)ら。これはある種の防腐剤が寒天による物 理的吸着現象の結果活性低下を起すことによるものと考 えられているが拡散しやすい物質が製品中に共存してい る場合は，その阻止帯はあまり意味がない。また防腐剂 単体の抗菌性を評価する場合はよいとしても防腐剤と他 の成分閒の相関関係を理解するためには不都合である。

$4 \cdot 2 \cdot 1$ カップ法

この方法は日本抗生物質医薬品基準（1967) ${ }^{19 ）}$ にその 詳細が規定されているので参考にするとよい。しかし化 粧品の場合は製品の性質上，抗生物質とは若干異にする 所もあるので簡単に記してみたい。

イ）菌液の調製

斜面培養菌を種菌として液体培地 $10 \mathrm{~m} l$ に少量 (白金 耳あるいは白金線にて) 移植して $30 \sim 37^{\circ} \mathrm{C}, 18 \sim 24$ 時間 培養し菌液とする。この菌液 1 $2 \mathrm{~m} l$ をすでに溶かして (寒天培地) $48 \sim 53^{\circ} \mathrm{C}$ に保温されている寒天培地 $100 \mathrm{ml}$ に加え, よく混和して試験菌液とする。

ロ）カップ用寒天平板

シャーレ(通常内径 $90 \mathrm{~mm}$ ) に寒天培地 $20 \mathrm{ml}$ を分注 して均等にかたまらせて平板とする。これにイ）の試験 菌液 $4 \mathrm{~m} l$ を平らに重層するように分注してかたまらせ る。カップ (外径 $7.9 \sim 8.1 \mathrm{~mm}$, 内径 $5.9 \sim 6.1 \mathrm{~mm}$, 高さ $9.9 \sim 10.1 \mathrm{~mm}$ ) を適当数（抗生物質の場合は 4 ケ） を等間隔になるように置き平板とする。

\section{八）検体の調製}

製品そのまま, あるいは適当な希釈液をカップ内に気 泡の入らないように満たす。また対照としては製品に添 加された防腐剤の濃度を対照として用いる。

二)培 養

カップを立てたまま $30 \sim 37^{\circ} \mathrm{C}, 18 \sim 24$ 時間培養した後 阻止帯の径を測定して比較検討する。

$4 \cdot 2 \cdot 2$ 重層法

$4 \cdot 2 \cdot 1$ イ)の試験菌液を小試験管に適当量分注しその 上に検体(場合によっては希釈液)を重層して $30 \sim 37^{\circ} \mathrm{C}$, 18〜24時間培地した後阻止帯の長さを比較検討する。

$4 \cdot 2 \cdot 3$ 比濁法

この方法は製品に添加される防腐剤単体の抗菌活性を みるのにはよいが製品中での防腐効果を評価するのには 不都合である。また完全発育阻止を必要としないような 場合にはよい方法で液体培地に一定濃度の被検液を入れ て30 37 ${ }^{\circ} \mathrm{C}$ で静置培養あるいは振盪培養（多くは後者 が利用さている）により一定時間後の発育の溷度濁を比 濁計を用いて（ブイヨン培養の場合は波長 $650 \mathrm{~m} \mu$ にお ける）吸光度を測定する。この方法は精度は高いし短時 
間で結果が出せる利点はあるが，はじめから被検液に濁 りのある検体には不適当である。

操作は斜面培養で $30 \sim 37^{\circ} \mathrm{C}, 18 \sim 24$ 時間培養しこれ よりごく少量を $10 \mathrm{~m} l$ の液体培地に接種して $30 \sim 37^{\circ} \mathrm{C}$, 18 24時間培養したものを菌液とする。次に防腐剂加液 体培地 $9.9 \mathrm{~m} l$ にその菌液 $0.1 \mathrm{~m} l$ を接種して静置あるい は振盪培養にうつる。培養は $30 \sim 37^{\circ} \mathrm{C}$ で行ならが測定 時間は通常 30 分または 1 時間間隔とし，これを対数に読 みかえることによりプロットするとその増殖曲線がえら れる。この曲線の状態により防腐剤の抗菌作用が縕胞分 裂のどのような発育期例えば誘導期, 対数期あるいは定 常期等のいずれで作用を発揮するかがわかる。しかし正 確には各使用菌株によってそれぞれの条件を異にする。 たとえば振盪培養の場合は振幅, 振蕰回数, 温度, 培 地, 接種菌量等により得られる結果も異なってくるがゆ えに一定条件下での成績を求めるようにしなければなら ない。

Gain (1947) ${ }^{36)}$ らは第 4 級アンモニウム塩の殺菌効果 を簡易急速測定法として比濁計を利用した報告をしてい るがWailes (1962) ${ }^{38)}$ はマノメーター法についての報告 をしている。この方法は従来のワールブルグ検圧計を利 用したもので防腐剤の試験としては短時間で結果が読み とれる利点はあるが，その操作において技術的問題が関 与することに留意しなければならない。

防腐剤の効果を評価するには上記のいずれか 1 つの方 法だけにたよることは危険であって少なくとも $2-3$ の 方法による判別を行ならべきである。通常変敗を起す微 生物はその種類のうえでは真菌よりも細菌の方がはるか に多い。しかし乳剤を例にみれば一般細菌は肉眼的にそ の発育を発見することはでききないが真菌とくにカビは その限りでない。またこ机を発育に要する日数からみれ ば製品に含まれる成分あるいは製造環境によっても異な るが一般細菌は比較的短時日で増殖するのに対しカビは 長い潜伏期間後に肉眼で見える程度に繁殖して来る。し たがってでき上った製品の防腐試験においても普通防腐 剤添加製品と無添加製品との比較試験が必要となってく る。あるいはこれに貯蔵試験（常温, 苛酷試験）を行な らべきである。次に接種試験を行ならのも 1 法である。 それはある一定期間後にもしも菌を接種した製品である ならば，その発育により菌が増えているか，否か，また は接種菌数に対比して減少しているか, 否かの 2 通りの 方法で検討してみるのである。一方試験菌を接種しない 製品では製造後菌が污染されているか否かの経時変化も 同時に究明しなければならないと思われる。

なお化粧品品質基準 (1967) ${ }^{111}$ において規定されている
品目中で主に防腐剤に関与すると思われるものを選らび 著者が寒天平板法で行なった抗菌活性值を参考までに

Table-8 に示した $(1971)^{38) 。}$

すなわちこの表からもわかるように試験菌によっては 数 $\mu \mathrm{g} / \mathrm{m} l$ で発育阻止作用のみられる化合物も緑膿菌に 対してはほとんどの化合物が約 100 1000 倍以上の高濃 度を心要とし，化合物単体で広、スペクトルをもったも のはみあたらないことが 1 目でわかる。しかしこの活性 值も試験法およびその作用条件をかえることによっては， またその活性值に変動を生ずることはいらまでもない。

\section{5.むすび}

化粧品の微生物污染がぞのようにして起るかについて は，まず製品に使用される材料からすべて無菌的操作の もとで衛生的に製造されているかどらかにかかってく る。しかしその製造にあたっては各社が秘伝とも思われ る方法で極秘の研究にたよっている現状ではその実態を つかむことは困難で使用者側にあたえる不安も解消する ことはできない。

最近 Wolven (1971)39) は FDA に扔ける化粧品に関 する会合での報告で多くの忠告をしている。その主たる ものは消費者の場に立って製品を考雀造することにあ るとしている。たとえば防腐剤についてみれば多くの種 類をもつ化粧品それぞれに少なくとも5 種類の微生物を

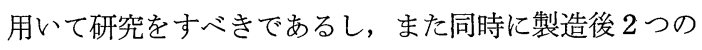
ことなる温度条件で28日間の経時変化および毒性試験を 行ならべきであるとしている。もちろん製品中に病原菌 を発見してはならないことはいらまでもないが, この他 に非刺激性, 非感作性, 処方成分と適合性であること, 抗菌活性に広いスペクトルをもつこと, 安全性, 製品の 色や臭に影響を与えないこと等をあげている。また防腐 剤を抗菌性の面からみると次のようなことが考えられ る。

1）防腐剤が化粧品中の成分あるいは微生物の死菌成 分と反応して不活性な複合体を作り防腐剤の有効濃度が 本質的に減少する。

2）微生物の発育による過程で防腐剤が不活性な形に 変化するために有効濃度が減少する。

3）微生物の発育にともない製剤中の $\mathrm{pH}$ が変化し防 腐剤の解離状態が変化して活性が低下する場合。

4）防腐剤に抵抗性の変異菌の出現とその増殖による 防腐剛の活性低下

いずれにしても化粧品中に微生物污染を起させないよ らな配慮を望むところであるが，本来無菌性を要求する ことはコスト面からいって無理と思われる。それでわが 


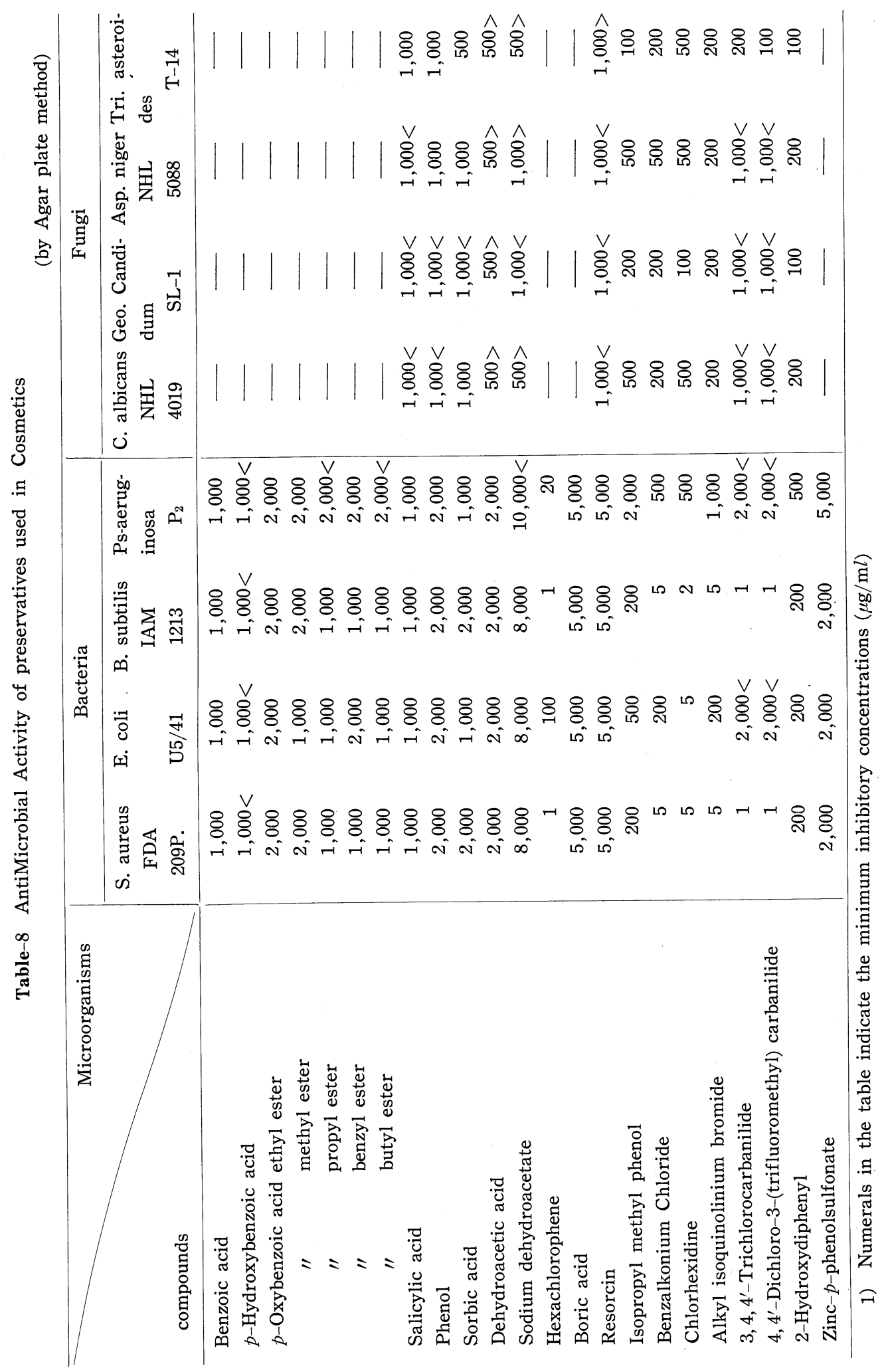


国では眼軟蓑において50個以下と現在規定されており， また欧米では 100 個以下の生菌数が要求されている。し たがって著者も便宜的にこれら数值以下の生菌数であっ てほしいことを提案したい。また著者は化粧品関係の製 品ではとくに一般生菌数の外にグラム陽性菌としてブド ウ球菌, グラム陰性菌として緑膿菌を污染菌の指標とし てはと考えている。それは化学物質による抵抗性の問題 で一般にブドウ球菌は弱いが，緑膿菌はかなり抵抗性が 強いことを強調しておきたい。しかしながら微生物の試 験は化学試験が器械で処理されるのとことなり人為的に 操作することと永年の経験と知識をもととした判断によ らざるをえない困難さがある。しかし最近の化粧品中の 化学物質の安全性に対する世論の注目もさることながら 微生物污染の問題もここであらためて注目をしておく必 要があると思われる。そこで注意しなければならないこ とは防腐剤をあまり過大評価することはさけ，あくまで 2 次污染の防腐に対してのみその使用目的をおくべきで あると結論したい。

\section{文献}

1) FDA papers; 4 (No.2) 21 (1970)

2) Knüsel, F., Hess, H. K., and Lim, W., Proc. Eurp. Soc. for the Study Drug toxicity., 10, 139 (1969)

3) Tenenbaum, S., Am. perfumer and Cosmetic., 86, 33 (1971)

4) Noble, W. C., Lancet., 1, 347 (1966)

5) Ayliffe, G. A. J., Lowburg, E, J, L., Hamilton, J. G., Small, J. A., Asheshow, E. A., and Parker ; M. T., Lancet., 11, 365 (1965)

6) Barker, J. H., J. Soc. cosmet. Chem., 10, 133, (1959)

7) Schiller, I., Kuntscher, H., Wolff, A., and Nekola, M., App. Microbiol., Dec. 1924 (1968)

8) De Navarre., Am. perfumer and cosmetic., 84, 22 (1969)

9) Alquire, D.E., Am. perfumer and Cosmetic., 85, 31 (1970)

10) Davis, J. G., J. pharm., Lond. Suppl. 12, 29 T (1960)

11）化粧品品質基準 - 厚生省告示第 321 号, p. 6 (1967)

12) Wedderburn, D. L., Ad. pharmaceut. Sci., 1, 195 (1964)

13) Foter, M. J., and Nisonger, L, L., Ann. New York Acad. Sci., 53, 112 (1950)
14) Stearman, R. L., Bact. Rev., 19, 160 (1955)

15) Norris, J. R., and Ribbons, D. W., Methods in Microbiology., 1, 593 Academic press London \& New York (1969)

16) 植村定次郎, 福見秀雄, 柳田友道、微生物生理学, p. 138., 朝倉書店 (1960)

17) Postgate, J. R., Methods in Microbiology., 1, 611., Academic press London \& New York (1969)

18）衛生検査指針（III）厚生省， p. 131 協同医書出版社 (1950)

19）日本抗生物質医薬品基準 - 厚生省, p. 468 (1969)

20) Woodward, C. R., and Mc Namara, T. F., Am. perfumer and Cosmetic., 86, 29 (1971)

21) USP., XVIII, p. 849 , p. 853 (1970)

22) N. F., XII, p. 958 (1970)

23）岩原繁雄, Medical apparatus Culture., 11, 16 (1970)

24）日本薬局方第 7 改正第 1 部解説書, p. B-110広川書 店 (1961)

25) BBL Manual of Products and Laboratory procedures., 5th Ed. (1968)

26) Lawrence, C. A., Ann. New. York. Acad. Sci., 53, 66 (1950)

27) Lawrence, C. A., Soap. perfumery and cosmetic., 27, 369 (1954)

28) Quisno, R. A., Gibby., I. W., and Fother, M. J., J. Am. Pharmaceutical Assoc., 35, 317 (1946)

29) Klărman, G. G., and Wright, E. S., Am. J. Pharmacy., 120, 1 (1948)

30) Brown, M. R. W., and Richards, R.M.E., J. pharm. pharmacol., 16, $41 \mathrm{~T}$ (1964)

31）青木大, 鎌田盿, 松崎藤一郎, 中谷治実, 薬学雑誌 77, 410 (1957)

32) Gucklhorn, I. R., Manufacturing Chemist \& Aerosol News., Second Series part 1, 44 (1970)

33) Croshaw, B., Groves, M. J., and Lessel, B., J. pharm. pharmacol., 16, 127 (1964)

34) Schuster, G., and Modde, H. K., Am. perfumer and cosmetic., 86, 37 (1971)

35) Klarmann, E.G., Am. J. pharmacy., 128, 1 (1956)

36) Gain, J. F., and Lawrence, C. A., Science., 106, 525 (1947)

37) Wailes, J. L., J. pharm. Sci., 51, 165 (1962)

38）石関忠一; 衛生試験所報告, 89投稿中（1971）

39) Wolven, A., Am. perfumer and Cosmetic., 86, 47 (1971) 